ISSN : 2615-1995, E-ISSN : 2615-0654

J. Madani., Vol. 1, No. 2, September 2018 (305-322)

(c)2018 Lembaga Kajian Demokrasi

MADANI

dan Pemberdayaan Masyarakat (LKD-PM)

\title{
PENGARUH KUALITAS PELAYANAN, HARGA, DAN KUALITAS PRODUK TERHADAP KEPUASAN PELANGGAN INSTRUMEN PENUNJANG LABORATORIUM (STUDI KASUS PADA PT. LABORINDO SARANA JAKARTA)
}

\author{
Ratih Andalusi \\ Fakultas Ekonomi Universitas Pamulang \\ ratichkhu@yahoo.co.id
}

\begin{abstract}
Abstrak
Penelitian ini bertujuan untuk menganalisis pengaruh kualitas pelayanan harga dan kualitas produk terhadap kepuasan pelanggan instrument penunjang laboratorium di PT Laborindo Sarana. Teknik analisis data yang digunakan analisis deskriptif dan analisis statistik inferesial yaitu: 1. Uji Validitas dan Reliabilitas, 2. Uji Asumsi Klasik, 3.Analisis Regresi Berganda, 4.Analisis Koefisien Determinasi (R2), 5. Pengujian Hipotesis dengan Uji Parsial (uji t) dan Uji Simultan (uji F). Hasil Pengujian dan analisisnya menunjukkan: 1) Kualitas pelayanan tidak berpengaruh signifikan terhadap kepuasan pelanggan PT Laborindo Sarana karena nilai signifikan diatas 0,05 dan nilai $t_{\text {hitung }}(0,512)<$ nilai $t_{\text {tabel }}(1,988)$ dengan bentuk pengaruhnya adalah positif karena nilai koefisien regresi kualitas pelayanan bernilai positif, yaitu 0,037. 2) Harga berpengaruh signifikan terhadap kepuasan pelanggan PT Laborindo Sarana karena nilai signifikan $(0,000)$ dibawah 0,05 dan nilai $t_{\text {hitung }}(8,589)>$ nilai $_{\text {tabel }}(1,988)$ dengan bentuk pengaruhnya adalah positif karena nilai koefisien regresi harga bernilai positif, yaitu 0,467. 3) Kualitas Produk tidak berpengaruh signifikan terhadap kepuasan pelanggan PT Laborindo Sarana karena nilai signifikan diatas 0,05 dan nilai $t_{\text {hitung }}(0,030)<$ nilai $t_{\text {tabel }}(1,988)$ dengan bentuk pengaruhnya adalah positif karena nilai koefisien regresi kualitas pelayanan bernilai positif, yaitu 0,002. 4) Kualitas pelayanan ( $\left.X_{1}\right)$, harga $\left(X_{2}\right)$, dan kualitas produk $\left(X_{3}\right)$, berpengaruh positif dan signifikan secara simultan terhadap keputusan pembelian $(Y)$ karena nilai signifikan $(0,000)$ dibawah 0,05 dan nilai $F_{\text {hitung }}(24,855)>$ nilai $F_{\text {tabel }}(2,70)$ dengan besarnya pengaruh Kualitas pelayanan $\left(X_{1}\right)$, harga $\left(X_{2}\right)$, dan kualitas produk $\left(X_{3}\right)$ terhadap kepuasan pelanggan instrumentasi penunjang laboratorium PT Laborindo Sarana sebesar $42 \%$.
\end{abstract}

Kata Kunci: Kualitas Pelayanan, Harga, Kualitas Produk dan Kepuasan Pelanggan

\section{PENDAHULUAN}

\section{Latar Belakang}

Pesatnya pertumbuhan industri nasional menjadikan Indonesia sebagai pasar potensial bagi peralatan laboratorium. Globalisasi membawa dampak yang sangat besar bagi perkembangan riset di Indonesia, sehingga menciptakan pasar yang terbuka luas dan peluang menjadi semakin lebar, hal ini diikuti berkembangnya berbagai macam distributor dan business partner dibidang peralatan laboratorium pene- litian di Indonesia, salah satunya adalah PT Laborindo Sarana. Perusahan ini menyediakan berbagai jenis barang kebutuhan dasar sampai kebutuhan khusus pelanggannya yaitu para peneliti, sehingga menciptakan hubungan erat terhadap pelanggan (kualitas pelayanan). Semakin tinggi tingkat persaingan bisnis, maka organisasi perusahaan dituntut agar mencapai keunggulan kompetitif (competitive advantage) supaya dapat memenangkan persaingan dalam bisnis. Untuk mencapai hal itu pemasar harus 
menerapkan konsep pemasaran modern yang berorientasi pelanggan karena mereka merupakan ujung tombak keberhasilan pemasaran (Tjiptono, 2005: 100). Lebih lanjut menurut Parasuraman dalam Lupiyoadi (2006) peningkatan kualitas layanan pada umumnya difokuskan dalam persepsi yang berhubungan dengan berwujud, kehandalan, daya tanggap, jaminan, empati yang dapat diukur dengan instrumen SERVQUAL.

Hasil pengukuran dengan instrumen tersebut memberikan informasi tentang seberapa jauh layanan yang diberikan oleh perusahaan dapat memenuhi harapan pelanggan. Mengingat semakin bertambahnya waktu yang menyebabkan semakin bertambahnya jumlah pelanggan, diikuti dengan meningkatnya jumlah perusahan serupa sehingga menimbulkan persaingan antar sesama perusahaan, mau tidak mau PT Laborindo Sarana harus mengembangkan strategi untuk menjaga para pelanggannya dengan cara meningkatkan kualitas pelayanan, memperluas teknologi produk dan menentukan harga yang sesuai dengan keadaan pasar riset. PT Laborindo Sarana merupakan distributor exclusive dari beberapa brand alat dan bahan penunjang laboratorium penelitian yang berdiri semenjak tahun 1992, dipimpin oleh seorang direktur utama yang merangkap juga sebagai komisaris.

Saat ini PT Laborindo Sarana memiliki 2 divisi yaitu divisi Instrumentasi laboratorium, serta divisi bahan habis pakai (consumable) yang mensupplai kebutuhan laboratorium riset dan testing rutin. Ada berbagai brand Instrumentasi penunjang laboratorium yang diageni oleh perusahaan ini yaitu : SCIEX (LiquidChromatography MassSpectrofotometer), Cascada (Water Purifier), Hygiena (Hygiene Monitoring), Delta Instrument (Milk Analyzer) CELCIS (Rapid Test). Sedangkan untuk produk consumable PT.Laborindo Sarana mengageni brand Whatman (Filter Paper), SIGMA ALDRICH (Kromatografi consumable item) dan Biologix (Pippete Tips).

Setiap produk yang diageni oleh PT Laborindo Sarana berasal dari luar negeri, dimana untuk mendatangkannya dan mensupplai ke pelanggannya diperlukan izin yang di tetapkan oleh pemerintah di dalam aturan kementrian perdagangan nomor 74/M-DAG/ PER/12/2012 Tentang alat ukur, timbang dan perlengkapannya asal impor. Sedangkan untuk barang habis pakai (consumable) yang berupa bahan kimia, Proses perizinannya lebih ketat, misalnya jika perusahaan ini ingin mengimpor bahan berbahaya (B2) seperti misalnya merkuri, besi oksida (seperti misalnya Red Iron Oxide) ataupun besi hidroksida, salah satunya adalah IP Bahan Berbahaya (B2) atau Importir Produsen Bahan Berbahaya (IP-B2) berdasarkan Peraturan Menteri Perdagangan nomor 75/M-DAG/PER/10/2014 tentang Perubahan Kedua atas Peraturan Menteri Perdagangan Nomor 44/M-DAG/PER/9/2009 tentang Pengadaan, Distribusi, dan Pengawasan Bahan Berbahaya. Kesuksesan dalam persaingan akan dapat dipenuhi apabila perusahaan bisa menciptakan dan mempertahankan pelanggan (Tjiptono, 2006: 9).

Produk yang berkualitas dengan harga yang bersaing merupakan kunci utama dalam memenangkan persaingan, yang pada akhirnya akan dapat memberikan nilai kepuasan yang lebih tinggi kepada pelanggan. Seorang penjual harus memberikan kualitas produk yang dapat diterima karena jika tidak, pelanggan akan beralih kepada pesaing (Kurniawan, 2009: 1). Tingkat kepuasan pelanggan dipengaruhi oleh beberapa faktor yang sering kita jumpai seperti kualitas produk, harga dan kualitas pelayanan.

Untuk mengatasi rendahnya tingkat kepuasan pelanggan maka salah satu upaya yang dilakukan oleh perusahaan adalah dengan menerapkan strategi meningkatkan kualitas pelayanan. Mengingat tingkat persaingan terus meningkat, maka pihak perusahaan harus meningkatkan kinerja perusahaan termasuk peningkatan pelayanan, untuk membangun hubungan jangka panjang dengan pelanggannya atau calon pelanggan lain. Berkaitan dengan pentingnya masalah pelayanan dan harga, maka hal ini perlu diperhatikan oleh PT Laborindo dalam upaya untuk mengantisipasi persaingan yang semakin ketat dengan perusahaan distributor alat laboratorium lainnya, serta untuk lebih meningkatkan penjualan, maka perusahaan perlu melakukan evaluasi mengenai kualitas pelayanan dan mengetahui harga yang diatur oleh perusahaan.

Melihat tantangan dan kenyataan dilapangan yang dihadapi perusahaan dalam menghadapi persaingan dunia bisnis, maka dilakukan penelitian pada perusahaan PT 
Laborindo Sarana, Dengan mengambil judul: "PENGARUH KUALITAS PELAYANAN, HARGA DAN KUALITAS PRODUK TERHADAP KEPUASAN PELANGGAN INSTRUMEN PENUNJANG LABORATORIUM PT LABORINDO SARANA"

\section{Pembatasan Masalah}

Dengan keterbatasan peneliti serta agar lebih mudah di pahami dan dimengerti maka penelitian ini penulis memberikan batasanbatasan yang diteliti, yaitu hanya kualitas pelayanan, harga dan kualitas produk terhadap kepuasan pelanggan di PT Laborindo Sarana, dengan cara melakukan penyebaran kuesioner kepada pelanggan.

\section{Perumusan Masalah}

Berdasarkan batasan masalah diatas, maka masalah-masalah penelitian dapat dirumuskan sebagai berikut:

1. Apakah kualitas pelayanan berpengaruh signfikan terhadap kepuasan pelanggan Instrumentasi Laboratorium di PT Laborindo Sarana?

2. Apakah harga instrumentasi laboratorium berpengaruh signifikan terhadap kepuasan pelanggan di PT Laborindo Sarana?

3. Apakah kualitas produk berpengaruh signifikan terhadap kepuasan pelanggan instrumentasi laboratorium di PT Laborindo Sarana?

4. Apakah kualitas pelayanan, harga dan kualitas produk secara simultan berpengaruh signifikan terhadap kepuasan pelanggan PT Laborindo Sarana?

\section{Tujuan Penelitian}

Penelitian ini bertujuan untuk mengetahui dan menganalisis:

1. Pengaruh kualitas pelayanan terhadap kepuasan pelanggan PT Laborindo Sarana.

2. Pengaruh kualitas produk terhadap kepuasan pelanggan PT Laborindo Sarana.

3. Pengaruh harga terhadap kepuasan pelanggan PT Laborindo Sarana.

4. Pengaruh kualitas pelayanan, harga dan kualitas produk terhadap kepuasan pelanggan PT Laborindo Sarana.

\section{Tinjauan Pustaka}

\section{Manajemen}

Mary Parker Follet, mendefinisikan manajemen sebagai seni menyelesaikan pekerjaan melalui orang lain. Definisi ini berarti bahwa seorang manajer bertugas mengatur dan mengarahkan orang lain untuk mencapai tujuan organisasi. Ricky W. Griffin mendefinisikan manajemen sebagai sebuah proses perencanaan, pengorganisasian, pengkoordinasian, dan pengontrolan sumber daya untuk mencapai sasaran (goals) secara efektif dan efesien. Efektif berarti bahwa tujuan dapat dicapai sesuai dengan perencanaan, sementara efisien berarti bahwa tugas yang ada dilaksanakan secara benar, terorganisir, dan sesuai dengan jadwal.

Lawrence A. Appley berpendapat bahwa pengertian manajemen merupakan keahlian untuk menggerakkan orang agar melakukan sesuatu. George R. Terry, mengatakan bahwa manajemen merupakan prosesya yang khas yang terdiri dari tindakan-tindakan: perencanaan, pengorganisasian, menggerkan dan pengawasan yang dialkukan untuk menentukan serta mencapai sasaran-sasaran yang telah ditetapkan melalui pemanfaatan sumber daya manusia serta sumber-sumber lain.

\section{Manajemen Pemasaran}

Pengertian manajemen menurut R. Terry adalah suatu proses khas terdiri tindakantindakan perencanaan, pengorganisasian, penggerakan dan pengontrolan yang dilakukan dalam menentukan serta mencapai target yang sudah ditetapkan lewat pemanfaatan sumberdaya manusia dan lainnya. Sedangkan manajemen pemasaran menurut Kottler (2012) adalah penganalisaan, perencanaan, pelaksanaan program-progam yang ditujukan untuk mengadakan pertukaran dengan pasar yang dituju untuk mencapai tujuan organisasi.

\section{Pemasaran}

Konsep pemasaran yaitu suatu falsafah manajemen dalam bidang pemasaran yang berorientasi kepada kebutuhan dan keinginan konsumen dengan didukung oleh kegiatan pemasaran terpadu yang diarahkan untuk memberikan kepuasan konsumen sebagai kunci keberhasilan organisasi dalam usahanya mencapai tujuan yang telah ditetapkan. Jadi, konsep pemasaran merupakan orientasi peru- 
sahaan yang menekankan bahwa tugas pokok perusahaan adalah menentukan kebutuhan dan keinginan pasar, dan selanjutnya memenuhi kebutuhan dan keinginan tersebut sehingga dicapai tingkat kepuasan langganan yang melebihi dari kepuasan yang diberikan oleh para saingan menurut Sofjan Assauri (2003: 22).

\section{Kualitas Pelayanan}

Pelanggan umumnya mengharapkan produk berupa barang atau jasa yang dia konsumsi dapat diterima atau dinikmatinya dengan pelayanan yang baik atau memuaskan. Dengan perkataan lain para pelanggan menginginkan mutu pelayanan yang diberikan adalah baik dan memuaskan. Perusahaan harus memperhatikan mutu dari jasa (service quality) dan pelayanan yang diberikan oleh perusahaannya. Dalam hal ini perusahaan tentunya berupaya untuk memberikan jasa atau pelayanan (service quality) yang baik kepada pelanggannya. Hal ini merupakan upaya perusahaan untuk dapat tampil bedanya perusahaan tersebut dengan para pesaingnya.

Menurut Tjiptono (2013 : 110): "Kualitas jasa atau kualitas pelayanan yang mendefinisikan sebagai kondisi dinamis yang berhubungan dengan produk, jasa, sumber daya manusia, proses dan lingkungan yang memenuhi atau melebihi harapan."

Terdapat lima dimensi yang penting dari mutu jasa atau pelayanan, yaitu pertama adalah tampilan berwujud atau tangibles yang berbentuk fasilitas fisik, peralatan, personalia dan bahan-bahan komunikasi. Kedua adalah sesuatu hal yang dapat dipercaya atau reliability yaitu kemampuan untuk menyediakan jasa yang dijanjikan secara tepat dan dapat dipercaya. Ketiga adalah cepat tanggap atau responsiveness, yaitu keinginan untuk membantu pelanggan dan memberikan jasa yang cepat dan tepat. Keempat adalah jaminan atau assurance yang berupa pengetahuan dan keramahan karyawan serta kemampuan untuk memberitahukan secara meyakinkan dan dapat dipercaya. Kelima adalah rasa yang terdapat pada diri seseorang untuk tidak menggunakan emosinya, atau empathy, karena sangat kuat menekankan perhatiannya kepada orang lain yang dapat diberikan perusahaan kepada pelanggan.

\section{Harga}

Harga merupakan satu-satunya unsur marketing mix yang menghasilkan penerimaan penjualan, sedangkan unsur lainnya hanya unsur biaya saja. Walaupun penetapan harga merupakan persoalan penting, masih banyak perusahaan yang kurang sempurna dalam menangani permasalahan penetapan harga tersebut. Karena menghasilkan penerimaan penjualan, maka harga mempengaruhi tingkat penjualan, tingkat keuntungan, serta share pasar yang dapat dicapai oleh perusahaan. Penetapan harga selalu menjadi masalah bagi setiap perusahaan karena penetapan harga ini bukanlah kekuasaan atau kewenangan yang mutlak dari seorang pengusaha.

Seperti telah diutarakan di atas, dengan penetapan harga perusahaan dapat menciptakan hasil penerimaan penjualan dari produk yang dihasilkan dan dipasarkannya. Peranan penetapan harga akan menjadi sangat penting terutama pada keadaan persaingan yang semakin tajam dan perkembangan permintaan yang terbatas. Dalam keadaan persaingan yang semakin tajam dewasa ini, yang terutama sangat terasa dalam pasar pembeli (buyers market), peranan harga sangat penting terutama untuk menjaga dan meningkatkan posisi perusahaan di pasar, yang tercermin dalam share pasar perusahaan, di samping untuk meningkatkan penjualan dan keuntungan perusahaan. Sedangkan indikator yang mencirikan harga yang digunakan dalam penelitian ini, yaitu (Kotler 2012: 345) :
1 Keterjangkauan harga
2 Kesesuaian harga dengan kualitas produk
3 Daya saing harga

\section{Kualitas Produk}

Menurut Kotler (2010: 43) produk adalah segala sesuatu yang dapat ditawarkan kepada pasar untuk memuaskan suatu keinginan atau kebutuhan, termasuk barang fisik, jasa, pengalaman, acara, orang, tempat, properti, organisasi, informasi dan ide.

Jadi produk itu bukan hanya berbentuk sesuatu yang berwujud saja, seperti makanan, pakaian, dan sebagainya, akan tetapi juga sesuatu yang tidak berwujud seperti pelayanan jasa. Semua diperuntukkan bagi pemuasan kebutuhan dan keinginan (need dan wants) dari konsumen. Konsumen tidak hanya membeli 
produk sekedar memuaskan kebutuhan (need), akan tetapi juga bertujuan memuaskan keinginan (wants).

Menurut Mullins, Orville, Larreche, dan Boyd (2005: 422) apabila perusahaan ingin mempertahankan keunggulan kompetitifnya dalam pasar, perusahaan harus mengerti aspek dimensi apa saja yang digunakan oleh konsumen untuk membedakan produk yang dijual perusahaan tersebut dengan produk pesaing. Dimensi kualitas produk tersebut terdiri dari : performance (kinerja), durability (daya tahan), Features (Fitur) dan conformance to specifications (kesesuaian dengan spesifikasi).

\section{Kepuasan Pelanggan}

Kepuasan pelanggan adalah tingkat perasaan konsumen setelah membandingkan antara apa yang dia terima dan harapannya. Seorang pelanggan, jika merasa puas dengan nilai yang diberikan oleh produk atau jasa, sangat besar kemungkinannya menjadi pelanggan dalam waktu yang lama. Menurut Philip Kotler dan Kevin Lane Keller yang dikutip dari buku Manajemen Pemasaran mengatakan bahwa kepuasan konsumen adalah perasaan senang atau kecewa seseorang yang muncul setelah membandingkan kinerja (hasil) produk yang dipikirkan terhadap kinerja yang diharapkan (2012:177).

Kepuasan konsumen ini sangat tergantung pada persepsi dan harapan konsumen itu sendiri. Faktor-faktor yang mempengaruhi persepsi dan harapan konsumen ketika melakukan pembelian suatu barang atau jasa adalah kebutuhan dan keinginan yang dirasakan oleh konsumen tersebut pada saat melakukan pembelian suatu barang atau jasa, pengalaman masa lalu ketika mengkonsumsi barang atau jasa tersebut serta pengalaman teman-teman yang telah mengkonsumsi barang atau jasa tersebut dan periklanan.

Didalam lingkungan yang kompetitif, indikator yang dapat menunjukkan kepuasan konsumen adalah apakah konsumen tersebut akan membeli kembali dan menggunakan produk tersebut diwaktu yang akan datang.

\section{Hipotesis Penelitian}

Pengertian hipotesis menurut Sugiyono (2014) yaitu "Hipotesis merupakan jawaban sementara terhadap rumusan masalah. Karena sifatnya masih sementara, maka perlu dibuktikan kebenarannya melalui data empirik yang terkumpul". Adapun hipotesis yang penulis ajukan adalah sebagai berikut:

H1 : Diduga terdapat pengaruh positif dan signifikan antara kualitas pelayanan terhadap kepuasan pelanggan instrument penunjang laboratorium di PT Laborindo Sarana, Jakarta.

$\mathrm{H} 2$ : Diduga terdapat pengaruh positif dan signifikan antara harga terhadap kepuasan pelanggan instrument penunjang laboratorium di PT Laborindo Sarana, Jakarta.

H3 : Diduga terdapat pengaruh positif dan signifikan antara kualitas produk terhadap kepuasan pelanggan instrument penunjang laboratorium di PT Laborindo Sarana, Jakarta.

H4 : Diduga terdapat pengaruh positif dan signifikan antara kualitas produk,harga dan kualitas produk terhadap kepuasan pelanggan instrument penunjang laboratorium di PT Laborindo Sarana, Jakarta.

\section{METODOLOGI PENELITIAN \\ Tempat dan Waktu Penelitian}

Penulis mengadakan penelitian pada PT Laborindo Sarana, Jl. Alteri Raya No.8A Pondok Indah, Jakarta Selatan 12240. Telp : (021) 7255165,7257225 .

\section{Populasi dan Sampel Populasi}

Populasi adalah kumpulan yang lengkap dari elemen-elemen yang sejenis akan tetapi dapat dibedakan karena karakteristiknya (J Supanto, 2007). Populasi dalam penelitian ini adalah pengguna instrument PT Laborindo Sarana Populasi ini bersifat homogen dimana populasi merupakan pengguna instrumentasi laboratorium yang dijual oleh PT Laborindo Sarana.

\section{Sampel}

Dalam penelitian ini seluruh anggota populasi diambil atau bisa disebut sebagai sampel jenuh. Sampel jenuh adalah teknik penentuan sampel apabila semua anggota populasi digunakan sebagai sampel, Sugiyono, (2012: 
96). Hal ini sering dilakukan bila jumlah populasi relatif kecil, kurang dari 30 orang, atau penelitian yang ingin membuat generalisasi dengan kesalahan yang sangat kecil. Istilah lain sampel jenuh adalah sensus, dimana semua anggota populasi dijadikan sampel. Penelitian ini mengambil sampel semua pengguna instrumentasi yang di suplai oleh PT Laborindo Sarana.

\section{Variabel Penelitian}

Dalam penelitian ini terdapat dua variabel, yaitu variabel independent dan variabel dependen, seperti berikut :

1. Variabel bebas (independent variable) Variabel bebas yang dalam hubungannya dengan variabel lain bertindak sebagai penyebab atau yang mempengaruhi variabel dependen. Pada penelitian ini sebagai variabel independen yakni kualitas pelayanan, harga dan kualitas produk. Variabel independen sering disebut sebagai prediktor yang dilambangkan dengan $\mathrm{X}$.

2. Variabel terikat (dependent variable) Variabel yang tergantung dengan variabel lain, atau variabel yang dapat dipengaruhi oleh variabel lain. Sering disebut variabel respon di mana dalam penelitian ini adalah kepuasan pelanggan yang dilambangkan dengan $\mathrm{Y}$.

\section{Definisi Operasional Variabel}

Pengertian operasional variabel ini kemudian diuraikan menjadi indikator empiris yang meliputi :

1. Kualitas Pelayanan $\left(\mathrm{X}_{1}\right)$ Variabel ini diukur melalui indikator : a) Tangibles (bentuk fisik), b) Reliability (keandalan), c) Resposiveness (responsif), d) Assurance (rasa aman), e) Empaty (rasa nyaman).

2. Harga $\left(\mathrm{X}_{2}\right)$ Variabel ini diukur melalui indikator: kesesuaian harga dengan produk, daya saing harga dan keterjangkauan harga.

3. Kualitas Produk $\left(\mathrm{X}_{3}\right)$ Variabel ini diukur melalui indikator : performance (kinerja), durability (daya tahan), Features (Fitur), dan conformance to specifications (kesesuaian dengan spesifikasi).

4. Kepuasan Pelanggan (Y) Variabel ini diukur melalui indikator : Kepuasan pelanggan terhadap pelayanan, kepuasan terhadap produk yang di beli dan perbandingan antara harapan dan kenyataan.

\section{Metode Pengumpulan Data}

\section{Kuesioner}

Dalam penelitian ini untuk mendapatkan data primer kuantitatif, penulis menghubungi responden yaitu pelanggan yang merupakan pelanggan yang membeli dan menggunakan produk instrument penunjang laboratorium di PT.Laborindo Sarana, Jakarta.

\section{Wawancara}

Dalam penelitian ini untuk mendapatkan data primer kualitatif dengan metode wawancara, penulis datang ke kantor PT.Laborindo Sarana untuk melakukan studi dan melalukan wawancara ke beberapa pelanggan yang telah menjadi customer perusahaan tersebut.

\section{Studi Pustaka}

Penulis mendapatkan data sekunder dari buk-buku,jurnal dan beberapa sumber referensi yang mendukung tentang penelitian ini.

\section{Metode Analisis Data}

Metode analisis data yang digunakan dalam penelitan ini adalah:

\section{Uji Instrumen}

a. Uji Validitas

Menurut Grondlund (Ibrahim \& Wahyuni, 2012) validitas mengarah kepada ketepatan interpretasi hasil penggunan suatu prosedur evaluasi sesuai dengan tujuan pengukurannya. Validitas merupakan suatu keadaan apabila suatu instrumen evaluasi dapat mengukur apa yang sebenarnya harus diukur secara tepat. Suatu alat ukur hasil belajar matematika dikatakan valid apabila alat ukur tersebut benarbenar mengukur hasil belajar matematika. Validitas alat ukur tidak semata-mata berkaitan dengan kedudukan alat ukur sebagai alat, tetapi terutama pada kesesuaian hasilnya, sesuai dengan tujuan penyelanggaraan alat ukur (Surapranata, 2004). Dasar pengambilan keputusan untuk menguji validitas butir angket adalah:

Jika $\mathrm{r}_{\text {hitung }}$ positif dan $\mathrm{r}_{\text {hitung }}>\mathrm{r}_{\text {tabel }}$ maka variabel tersebut valid.

Jika $\mathrm{r}_{\text {hitung }}$ tidak positif serta $\mathrm{r}_{\text {hitung }}<\mathrm{r}_{\text {tabel }}$ maka variabel tersebut tidak valid. 


\section{b. Uji Reliabilitas}

Reliabilitas adalah alat yang digunakan untuk mengukur suatu kuesioner yang merupakan indikator dari suatu variabel. Menurut Ferdinand (2006) sebuah instrumen dan data yang dihasilkan disebut reliable atau terpercaya apabila instrumen tersebut secara konsisten memunculkan hasil yang sama setiap kali dilakukan pengukuran. Adapun cara yang digunakan untuk menguji reliabilitas kuesioner dalam penelitian ini adalah menggunakan rumus koefisien Alpha Cronbach, yaitu :

Apabila hasil koefisien Alpha > taraf signifikansi $60 \%$ atau 0,6 maka kuesioner reliable

Apabila hasil koefisien Alpha $<$ taraf signifikansi $60 \%$ atau 0,6 maka kuesioner tersebut tidak reliable.

Cronbach's Alpha. Ghozali (2013) mengklasifikasikan nilai Cronbach's Alpha sebagai berikut:

\begin{tabular}{|c|c|}
\hline \multicolumn{2}{|c|}{ Tabel 1. Pedoman Uji Reliabilitas } \\
\hline Nilai Cronbach's Alpha & Tingkat Reliabilitas \\
\hline $0,00-0,20$ & Kurang Reliabel \\
\hline $0,21-0,40$ & Agak Reliabel \\
\hline $0,41-0,60$ & Cukup Reliabel \\
\hline $0,61-0,80$ & Reliabel \\
\hline $0,81-1,00$ & Sangat Reliabel \\
\hline & Sumber : Gozali (2013) \\
\hline
\end{tabular}

\section{Uji Asumsi Klasik}

Uji asumsi klasik digunakan untuk mengetahui ketepatan sebuah data. Menurut Singgih Santoso (2011) berpendapat "Sebuah model regresi akan digunakan untuk melakukan peramalan, sebuah model yang baik adalah model dengan kesalahan peramalan yang seminimal mungkin. Karena itu, sebuah model sebelum digunakan seharusnya memenuhi beberapa asumsi, yang biasa disebut asumsi klasik". Dalam penelitian ini uji asumsi klasik yang digunakan adalah meliputi: uUji Normalitas, Uji Multikolinearitas, dan Uji Heterokedastisitas.

\section{a. Uji Normalitas}

Uji normalitas adalah pengujian tentang kenormalan distribusi variabel terikat dan variabel bebas dalam model regresi. Menurut Ghozali (2009), model regresi yang baik harus memiliki distribusi data normal atau penyebaran data statistik pada sumbu diagonal dari grafik distribusi normal. Pengujian normalitas dalam penelitian ini dilakukan dengan memperhatikan normal probability plot yang membandingkan distribusi kumulatif dari data sesungguhnya dengan distribusi kumulatif dari data normal. Sedangkan dasar pengambilan keputusan untuk uji normalitas data adalah (Ghozali, 2009):

1) Jika data menyebar disekitar garis diagonal dan mengikuti arah garis diagonal atau grafik histogramnya menunjukkan distribusi normal, maka model regresi memenuhi asumsi normalitas.

2) Jika data menyebar jauh dari diagonal dan atau tidak mengikuti arah garis diagonal atau grafik histogram tidak menunjukkan distribusi normal, maka model regresi tidak memenuhi asumsi normalitas.

\section{b. Uji Multikolinieritas}

Uji multikolinearitas bertujuan untuk menguji apakah model regresi ditemukan adanya korelasi antar variabel bebas/independen (Ghozali, 2009). Model regresi yang baik seharusnya tidak terjadi korelasi diantara variable independen. Jika variabel bebas saling berkorelasi, maka variabel ini tidak ortogonal. Variabel ortogonal adalah variabel bebas yang yang nilai korelasi antar sesama variabel bebas sama dengan nol. Deteksi untuk mengetahui ada tidaknya gejala multikolinearitas dalam model regresi penelitian ini dapat dilakukan dengan cara melihat nilai Variance Inflation Factor (VIF), dan nilai tolerance. Gejala multikolinearitas tidak terjadi apabila nilai VIF tidak lebih besar dari 10 serta nilai tolerance kurang dari 0,10. Untuk mendeteksi ada tidaknya multikoliniearitas dalam model regresi dapat dilihat dari tolerance value atau Variance Inflation Factor (VIF) dengan ketentuan sebagai berikut:

1) Jika nilai nilai tolerance lebih $>$ dari 0.1 dan nilai variance inflation factor (VIF) $<$ dari 10 , maka tidak terjadi multikolinieritas.

2) Jika nilai nilai tolerance lebih $<$ dari 0.1 dan nilai variance inflation factor (VIF) $>$ dari 10, maka terjadi multikolinieritas.

\section{c. Uji Heteroskesdastisitas}

Menurut Ghozali (2013) "Uji heteroskedastisitas bertujuan untuk mengetahui apakah dalam model regresi terjadi ketidaksamaan varian dari suatu residual pengamatan ke pengamatan lain". Untuk mengetahui ada tidak- 
nya heteroskedastisitas adalah dengan menggunakan uji scatter plot dengan melihat grafik antara nilai prediksi variabel terikat (ZPRED) dan nilai residualnya (SRESID) dengan ketentuan sebagai berikut :

1) Jika penyebaran titik-titik pada data scatter plot membentuk pola tertentu yang teratur seperti gelombang besar melebar, kemudian menyempit, atau dengan baik turun mengelompok menjadi satu, maka telah terjadi heteroskedastisitas.

2) Jika titik-titik menyebar diatas dan dibawah angka 0 pada sumbu Y tanpa membentuk pola tertentu, maka tidak terjadi problem heteroskedastisitas.

\section{Analisis Deskriptif dan Verifikatif}

a. Analisis Deskriptif

Analisis dilakukan dengan melihat frekuensi dari pilihan opsi oleh responden yang disediakan pada setiap pertanyaan kuesioner yang diberikan. Dalam penelitian ini, untuk pembobotan data, peneliti menggunakan skala pengukuran. Menurut Sugiyono (2014), skala pengukuran merupakan kesepakatan yang digunakan sebagai acuan untuk menentukan panjang pendeknya interval yang ada dalam alat ukur sehingga alat ukur tersebut bila digunakan dalam pengukuran akan menghasilkan data. Adapun skala pengukuran yang digunakan dalam penelitian ini adalah dengan skala Likert.

\section{b. Analisis Verivikatif}

Analisis kuatitatif merupakan penelitian untuk menilai kondisi dari nilai pengaruh dan signifikansi pengaruh tersebut. Menurut Sugiyono (2014) "Metode verifikatif merupakan penelitian yang bertujuan untuk mengetahui hubungan antara 2 (dua) variabel atau lebih". Dengan demikian dari hasil dari analisis ini akan memberikan jawaban awal dari rumusan masalah mengenai pengaruh variabel independen terhadap variabel dependen. Adapun tahapan analisis yang dilakukan meliputi:

1) Analisis Regresi Linier Sederhana

Analisis regresi liner sederhana ini dalam penelitian ini dimaksudkan untuk menganalisis pengaruh secara parsial antara variabel kualitas pelayanan $\left(\mathrm{X}_{1}\right)$, harga $\left(\mathrm{X}_{2}\right)$ dan kualitas produk $\left(\mathrm{X}_{3}\right)$ terhadap kepuasan pelanggan (Y).

2) Analisis Regresi Berganda

Analisis regresi regresi berganda dalam penelitian ini dimaksudkan untuk menganalisis pengaruh secara simultan/Bersama-sama antara variabel kualitas pelayanan $\left(\mathrm{X}_{1}\right)$, harga $\left(\mathrm{X}_{2}\right)$ dan kualitas produk $\left(\mathrm{X}_{3}\right)$ terhadap kepuasan pelanggan $(\mathrm{Y})$.

3) Analisis Koefisien Korelasi

Analisis ini bertujuan untuk mengetahui tingkat keterhubungan atau pengaruh masing-masing variabel independen terhadap variabel dependennya. Dalam hal ini kualitas pelayanan $\left(\mathrm{X}_{1}\right)$, harga $\left(\mathrm{X}_{2}\right)$ dan kualitas produk $\left(\mathrm{X}_{3}\right)$ terhadap kepuasan pelanggan (Y) baik secara parsial maupun secara simultan.

4) Analisis Koefisien Determinasi

Dalam penelitian ini untuk mengetahui berapa besar prosentase kontribusi dari variabel kualitas pelayanan, harga dan kualitas produk terhadap kepuasan pelanggan di Jakarta baik secara parsial maupun secara simultan.

5) Pengujian Hipotesis

Pengujian hipotesis dimaksudkan untuk menguji dugaan sementara yang dirumuskan dalam hipotesis berdasarkan data empiris. Dalam penelitian ini pengujian hipotesis dilakukan dengan uji t dan uji $\mathrm{F}$.

(a) Uji t (Parsial)

Uji t digunakan untuk menguji signifikansi variasi hubungan antar variabel $\mathrm{X}$ dan $\mathrm{Y}$, apakah variabel $\mathrm{X}_{1}, \mathrm{X}_{2}$ dan $\mathrm{X}_{3}$ benar-benar berpengaruh secara parsial terhadap variabel dependen Y.

(b) Uji F (Simultan)

Pengujian hipotesis simultan (Uji F) bertujuan untuk mengetahui pengaruh secara bersama-sama variabel independen terhadap variabel dependen.

\section{HASIL PENELITIAN DAN PEMBAHASAN Analisis Deskriptif Penelitian}

Bila dilihat dari tujuan penelitiannya, yang digunakan dalam penelitian ini adalah 
gabungan tipe kausal dan dekriptif. Riset dekriptif digunakan untuk memberikan gambaran terhadap karakteristik pasar, dalam hal ini responden, sedangkan tipe kausal yaitu penelitian yang mengukur kekuatan hubungan dua variabel atau lebih, juga untuk menunjukkan arah hubungan antara variabel bebas dengan variabel terikat (Mudrajad Kuncoro,2009:72), berguna untuk menganalisis hubungan-hubungan yang saling mempengaruhi sehingga dalam penelitian ini akan meneliti pengaruh variabel $\mathrm{X}_{1}, \mathrm{X}_{2}$ dan $\mathrm{X}_{3}$ terhadap variabel $\mathrm{Y}$. Pembobotan dilakukan dengan memberikan skor total dengan jumlah item dari variabel yang dibobot, melalui pertanyaaan yang diberikan penulis dalam kuesioner dapat di deskriptifkan setiap variabel yang diteliti.

Metode yang diambil dalam penelitian ini adalah metode pengukuran Likert. Dimana pertanyaan mengandung lima alternatif jawaban. Dan bentuk pertanyaan telah disusun menggunakan pengukuran Likert yang diberi bobot sebagai berikut:

\begin{tabular}{|c|c|}
\hline \multicolumn{2}{|c|}{ Tabel 2. Skala Likert } \\
\hline Jawaban & Bobot \\
\hline Sangat Baik (SB) & 5 \\
\hline Baik (B) & 4 \\
\hline Kurang Baik (KB) & 3 \\
\hline Tidak Baik (TB) & 2 \\
\hline Sangat Tidak Baik (STB) & 1 \\
\hline & Sumber : Sugiyono (2014) \\
\hline
\end{tabular}

Indeks $(\%)=($ Total Skor $/$ Skor Maksimum $)$ x 100. Maka dapat ditetapkan interval sebagai berikut :

\begin{tabular}{|c|c|}
\hline \multicolumn{2}{|c|}{ Tabel 2. Rentang Skala } \\
\hline Nilai Rata-rata & Jawaban \\
\hline $20.00 \%-36.00 \%$ & Tidak Baik \\
\hline $36.01 \%-52.00 \%$ & Kurang Baik \\
\hline $52.01 \%-68.00 \%$ & Cukup \\
\hline $68.01 \%-84.00 \%$ & Baik \\
\hline $84.01 \%-100 \%$ & Sangat Baik \\
\hline & Sumber : Sugiyono (2014) \\
\hline
\end{tabular}

\section{Variabel Kualitas Pelayanan $\left(\mathbf{X}_{1}\right)$}

Penilaian responden atas kualitas pelayanan dapat di paparkan sebagai berikut :

\begin{tabular}{|c|c|c|c|c|c|c|c|c|c|}
\hline \multirow{3}{*}{ No } & \multicolumn{9}{|c|}{ Tabel 3. Variabel kualitas pelayanan $\left(X_{1}\right)$} \\
\hline & \multirow{2}{*}{ Pernyataan } & SB & B & KB & C & TB & \multirow{2}{*}{ Total } & \multirow{2}{*}{ Skor } & \multirow{2}{*}{ Ket. } \\
\hline & & (1) & (2) & (3) & (4) & (5) & & & \\
\hline 1 & Kesesuaian barang yang di minta & $16 \%$ & $60 \%$ & $24 \%$ & $0 \%$ & $0 \%$ & $100 \%$ & $82.4 \%$ & Baik \\
\hline 2 & Product knowledge tenaga penjual & $7 \%$ & $46 \%$ & $38 \%$ & $8 \%$ & $1 \%$ & $100 \%$ & $83.1 \%$ & Baik \\
\hline 3 & Respon penjual terhadap pembeli & $3 \%$ & $33 \%$ & $51 \%$ & $13 \%$ & $0 \%$ & $100 \%$ & $84.5 \%$ & Baik \\
\hline 4 & Kecepatan merespon pembeli & $6 \%$ & $37 \%$ & $41 \%$ & $14 \%$ & $2 \%$ & $100 \%$ & $84.4 \%$ & Baik \\
\hline 5 & Penampilan penjual & $23 \%$ & $60 \%$ & $17 \%$ & $0 \%$ & $1 \%$ & $100 \%$ & $83.6 \%$ & Baik \\
\hline 6 & Sopan santun tenaga penjual & $31 \%$ & $57 \%$ & $10 \%$ & $2 \%$ & $0 \%$ & $100 \%$ & $85.4 \%$ & Baik \\
\hline 7 & Kemudahan proses pemesanan & $1 \%$ & $43 \%$ & $42 \%$ & $14 \%$ & $0 \%$ & $100 \%$ & $81.4 \%$ & Baik \\
\hline 8 & $\begin{array}{l}\text { Penjelasan customer service } \\
\text { mudah dipahami }\end{array}$ & $3 \%$ & $53 \%$ & $31 \%$ & $13 \%$ & $0 \%$ & $100 \%$ & $81.7 \%$ & Baik \\
\hline 9 & Tim Support melayani dengan baik & $18 \%$ & $58 \%$ & $24 \%$ & $0 \%$ & $0 \%$ & $100 \%$ & $83.3 \%$ & Baik \\
\hline \multirow[t]{2}{*}{10} & Lokasi kantor & $1 \%$ & $58 \%$ & $32 \%$ & $0 \%$ & $0 \%$ & $100 \%$ & $81.4 \%$ & Baik \\
\hline & \multicolumn{7}{|c|}{ Rata-rata Variabel kualitas pelayanan } & $83.9 \%$ & Baik \\
\hline
\end{tabular}

Bila dilihat dari tabel diatas rata-rata skor variabel kualitas pelayanan masuk pada interval $\mathbf{6 8 . 0 1 \% - 8 4 . 0 0 \%}$ atau dengan interpretasi setuju yang artinya responden mempunyai persepsi bahwa dalam melakukan penjualan, perusahaan dinilai mampu memberikan informasi yang tepat serta penjelasan yang meyakinkan kon- sumen perusahaan tersebut.

\section{Variabel Harga $\left(X_{2}\right)$}

Adapun penilaian responden atas harga yang dilaksanakan pada PT.Laborindo Sarana dapat di paparkan sebagai berikut: 


\begin{tabular}{|c|c|c|c|c|c|c|c|c|c|}
\hline \multicolumn{10}{|c|}{ Tabel 4. Variabel Harga $\left(\mathrm{X}_{2}\right)$} \\
\hline \multirow{2}{*}{ No } & \multirow{2}{*}{ Pernyataan } & SB & B & KB & C & TB & \multirow{2}{*}{ Total } & \multirow{2}{*}{ Skor } & \multirow{2}{*}{ Ket. } \\
\hline & & (1) & (2) & (3) & (4) & (5) & & & \\
\hline 1 & Keterjangkauan harga produk & $13 \%$ & $46 \%$ & $32 \%$ & $9 \%$ & $0 \%$ & $100 \%$ & $71.4 \%$ & Baik \\
\hline 2 & $\begin{array}{l}\text { Harga sesuai dengan kualitas } \\
\text { produk }\end{array}$ & $10 \%$ & $61 \%$ & $25 \%$ & $4 \%$ & $0 \%$ & $100 \%$ & $73.1 \%$ & Baik \\
\hline 3 & Harga sesuai dengan manfaat & $13 \%$ & $58 \%$ & $26 \%$ & $3 \%$ & $0 \%$ & $100 \%$ & $71.5 \%$ & Baik \\
\hline 4 & Harga yang ditawarkan kompetitif & $6 \%$ & $37 \%$ & $41 \%$ & $14 \%$ & $2 \%$ & $100 \%$ & $74.9 \%$ & Baik \\
\hline 5 & Kestabilan harga & $0 \%$ & $48 \%$ & $41 \%$ & $9 \%$ & $2 \%$ & $100 \%$ & $73.6 \%$ & Baik \\
\hline 6 & Harga mempengaruhi daya beli & $2 \%$ & $38 \%$ & $47 \%$ & $13 \%$ & $0 \%$ & $100 \%$ & $70.4 \%$ & Baik \\
\hline 7 & Harga mempengaruhi After Sales & $18 \%$ & $62 \%$ & $20 \%$ & $0 \%$ & $0 \%$ & $100 \%$ & $71.4 \%$ & Baik \\
\hline 8 & $\begin{array}{l}\text { Potongan harga mempengaruhi } \\
\text { daya beli }\end{array}$ & $11 \%$ & $60 \%$ & $20 \%$ & $7 \%$ & $2 \%$ & $100 \%$ & $71.7 \%$ & Baik \\
\hline 9 & Harga After Sales kompetitif & $18 \%$ & $58 \%$ & $24 \%$ & $0 \%$ & $0 \%$ & $100 \%$ & $73.3 \%$ & Baik \\
\hline \multirow[t]{2}{*}{10} & Kestabilan harga After Sales & $18 \%$ & $62 \%$ & $20 \%$ & $0 \%$ & $0 \%$ & $100 \%$ & $71.4 \%$ & Baik \\
\hline & \multicolumn{7}{|c|}{ Rata-rata Variabel Harga } & $73.9 \%$ & Baik \\
\hline & & & & & & & \multicolumn{3}{|c|}{ Sumber : Hasil Pengolahan Data Prime } \\
\hline
\end{tabular}

Bila dilihat dari tabel diatas rata-rata skor variabel minat beli sebesar $73.9 \%$ masuk pada interval $\mathbf{6 8 . 0 1 \% - 8 4 . 0 0 \%}$ atau dengan interpretasi setuju yang artinya responden mempunyai persepsi bahwa perusahaan memiliki harga yang sesuai dengan kualitas produk dan manfaat yang ditawarkan.

\section{Variabel Kualitas Produk $\left(\mathbf{X}_{3}\right)$}

Adapun penilaian responden atas variable kualitas produk yang dilaksanakan pada PT. Laborindo Sarana dapat di paparkan sebagai berikut:

\begin{tabular}{|c|c|c|c|c|c|c|c|c|c|}
\hline \multirow{3}{*}{ No } & \multicolumn{9}{|c|}{ Tabel 5. Variabel Kualitas Produk $\left(X_{3}\right)$} \\
\hline & \multirow{2}{*}{ Pernyataan } & SB & B & KB & $\mathbf{C}$ & TB & \multirow{2}{*}{ Total } & \multirow{2}{*}{ Skor } & \multirow{2}{*}{ Ket. } \\
\hline & & (1) & (2) & (3) & (4) & (5) & & & \\
\hline 1 & Kualitas produk yang ditawarkan & $22 \%$ & $35 \%$ & $37 \%$ & $6 \%$ & $0 \%$ & $100 \%$ & $83.8 \%$ & Baik \\
\hline 2 & Feature Produk instrumentasi & $15 \%$ & $44 \%$ & $37 \%$ & $4 \%$ & $0 \%$ & $100 \%$ & $88.1 \%$ & SB \\
\hline 3 & Daya tahan produk & $3 \%$ & $45 \%$ & $47 \%$ & $5 \%$ & $0 \%$ & $100 \%$ & $78.5 \%$ & Baik \\
\hline 4 & Kemudahan cara pakai produk & $5 \%$ & $56 \%$ & $34 \%$ & $5 \%$ & $0 \%$ & $100 \%$ & $74.4 \%$ & Baik \\
\hline 5 & Kemampuan produk instrumentasi & $18 \%$ & $55 \%$ & $24 \%$ & $2 \%$ & $1 \%$ & $100 \%$ & $82.6 \%$ & Baik \\
\hline 6 & Teknologi Produk & $3 \%$ & $59 \%$ & $35 \%$ & $3 \%$ & $0 \%$ & $100 \%$ & $75.4 \%$ & Baik \\
\hline 7 & Ketelitian produk & $10 \%$ & $59 \%$ & $30 \%$ & $1 \%$ & $0 \%$ & $100 \%$ & $81.9 \%$ & Baik \\
\hline 8 & Akses informasi tentang produk & $1 \%$ & $56 \%$ & $33 \%$ & $9 \%$ & $1 \%$ & $1 \%$ & $81.9 \%$ & Baik \\
\hline 9 & Garansi Produk & $18 \%$ & $58 \%$ & $24 \%$ & $0 \%$ & $0 \%$ & $100 \%$ & $88.3 \%$ & SB \\
\hline \multirow[t]{2}{*}{10} & After Sales Support & $3 \%$ & $42 \%$ & $44 \%$ & $10 \%$ & $1 \%$ & $3 \%$ & $82.4 \%$ & Baik \\
\hline & \multicolumn{7}{|c|}{ Rata-rata Variabel kualitas produk } & $86.9 \%$ & SB \\
\hline \multicolumn{10}{|c|}{ Sumber : Hasil Pengolahan Data Prime } \\
\hline
\end{tabular}

Bila dilihat dari tabel diatas rata-rata skor variabel kualitas produk sebesar $86.9 \%$ masuk

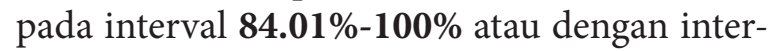
pretasi setuju yang artinya responden mempunyai persepsi bahwa produk produk instrumentasi yang jual oleh PT Laborindo Sarana memiliki kemampuan yang handal dengan kualtas yang sangat baik.

\section{Variabel Kepuasan Pelanggan (Y)}

Adapun penilaian responden atas variable kepuasan pelanggan yang dilaksanakan pada PT. Laborindo Sarana dapat di paparkan sebagai berikut: 


\begin{tabular}{|c|c|c|c|c|c|c|c|c|c|}
\hline \multicolumn{10}{|c|}{ Tabel 6. Variabel Kepuasan Pelanggan $(Y)$} \\
\hline \multirow{2}{*}{ No } & \multirow{2}{*}{ Pernyataan } & SB & B & KB & C & TB & \multirow{2}{*}{ Total } & \multirow{2}{*}{ Skor } & \multirow{2}{*}{ Ket. } \\
\hline & & (1) & (2) & (3) & (4) & (5) & & & \\
\hline 1 & Produk yang dibeli sesuai harapan & $7 \%$ & $57 \%$ & $31 \%$ & $5 \%$ & $0 \%$ & $100 \%$ & $83.4 \%$ & Baik \\
\hline 2 & $\begin{array}{l}\text { After Sales yang diberikan LS } \\
\text { memuaskan }\end{array}$ & $5 \%$ & $59 \%$ & $28 \%$ & $8 \%$ & $0 \%$ & $100 \%$ & $83.6 \%$ & Baik \\
\hline 3 & $\begin{array}{l}\text { Produk yang didapat sesuai } \\
\text { dengan penawaran yang diberikan }\end{array}$ & $2 \%$ & $54 \%$ & $43 \%$ & $1 \%$ & $0 \%$ & $100 \%$ & $87.5 \%$ & SB \\
\hline 4 & $\begin{array}{l}\text { Komitmen Perusahaan terhadap } \\
\text { pelanggan }\end{array}$ & $6 \%$ & $37 \%$ & $41 \%$ & $14 \%$ & $2 \%$ & $100 \%$ & $78.4 \%$ & Baik \\
\hline 5 & $\begin{array}{l}\text { Rekomendasi pelanggan untuk } \\
\text { produk }\end{array}$ & $4 \%$ & $41 \%$ & $42 \%$ & $12 \%$ & $1 \%$ & $100 \%$ & $73.6 \%$ & Baik \\
\hline 6 & $\begin{array}{l}\text { Konsistensi terhadap pelayanan } \\
\text { pelanggan }\end{array}$ & $5 \%$ & $31 \%$ & $52 \%$ & $12 \%$ & $0 \%$ & $100 \%$ & $75.4 \%$ & Baik \\
\hline 7 & Respon terhadap pelanggan & $3 \%$ & $53 \%$ & $38 \%$ & $6 \%$ & $0 \%$ & $100 \%$ & $81.4 \%$ & Baik \\
\hline 8 & $\begin{array}{l}\text { Keinginan pelanggan untuk re } \\
\text { Purchase }\end{array}$ & $9 \%$ & $51 \%$ & $35 \%$ & $5 \%$ & $0 \%$ & $100 \%$ & $81.7 \%$ & Baik \\
\hline 9 & Kualitas Barang sesuai harapan & $1 \%$ & $59 \%$ & $34 \%$ & $6 \%$ & $0 \%$ & $1 \%$ & $73.3 \%$ & Baik \\
\hline \multirow[t]{2}{*}{10} & $\begin{array}{l}\text { Mudah mengakses support dari } \\
\text { perusahaan }\end{array}$ & $1 \%$ & $58 \%$ & $32 \%$ & $0 \%$ & $0 \%$ & $100 \%$ & $84.4 \%$ & Baik \\
\hline & \multicolumn{7}{|c|}{ Rata-rata Variabel kualitas produk } & $82.9 \%$ & Baik \\
\hline
\end{tabular}

Bila dilihat dari tabel diatas rata-rata skor variabel kepuasan pelanggan sebesar $82.9 \%$ masuk pada interval $\mathbf{6 8 . 0 1 \% - 8 4 . 0 0 \%}$ atau dengan interpretasi setuju yang artinya responden mempunyai persepsi bahwa perusahaan memiliki kemampuan yang baik dalam hal pemenuhan keinginan dan kebutuhan sehingga pelanggan memiliki rasa kepuasan terhadap perusahaan.

\section{Pengujian Instrumen Data}

\section{Hasil Uji Valiiditas}

Perhitungan koefisien korelasi dilakukan dengan Software IBM SPSS (Statistical Program for Social Science) versi 24.00 for windows. Kuesioner dibagi dalam empat faktor utama, yaitu Kualitas Pelayanan $\left(\mathrm{X}_{1}\right)$ dengan 10 butir pernyataan, Harga $\left(\mathrm{X}_{2}\right)$ dengan 10 butir pernyataan ,Kualitas Produk $\left(\mathrm{X}_{3}\right)$ dengan 10 butir pernyataan dan Kepuasan Pelanggan (Y) dengan 10 butir pertanyaan, jumlah pernyataan dalam kuesioner sebanyak 40 butir pernyataan dengan jumlah responden sebanyak 100 responden. Perhitungan koefisien korelasi dilakukan dengan software SPSS 24.00, Uji signifikasi dilakukan dengan membandingkan nilai $\mathrm{r}_{\text {hitung }}$ dengan $r_{\text {tabel }}$ jika $r_{\text {hitung }}>r_{\text {tabel }}$ dan bernilai positif, maka variabel tersebut valid sedangkan jika $\mathrm{r}_{\text {hitung }}<\mathrm{r}_{\text {tabel }}$ maka variabel tersebut tidak valid. Hasil penelitian menunjukkan bahwa dari pengujian validitas seluruh butir pernyataan yang mempunyai nilai $\mathrm{r}_{\text {hitung }}$ lebih besar dari $\mathrm{r}_{\text {tabel }}$ Sehingga butir-butir pertanyaan dalam kuesioner tersebut dapat dikatakan valid dan dapat dijadikan acuan untuk penelitian selanjutnya.

\section{Hasil Uji Reliabilitas}

Berdasar perhitungan dengan menggunakan menggunakan Software IBM SPSS (Statistical Program for Social Science) versi 24.00 for windows. Seluruh butir pernyataan diperoleh nilai Cronbach Alfa lebih besar dari 0.60 dan nilai $r$ bernilai positif, dengan demikian maka butir pernyataan dalam variabel dalam penelitian dikatakan reliabel dan data layak untuk diolah ke pengujian berikutnya.

\section{Pengujian Asumsi Klasik}

\section{Uji Normalitas}

Uji normalitas dilakukan untuk menguji apakah dalam model regresi, variabel dependen dan variabel independen berdistribusi normal atau berdistribusi tidak normal. Berikut ini Hasil uji normalitas dengan alat uji KolmogorovSmirnov Test, sebagai berikut: 
Normal P.P Plot of Regression Standardized Residual

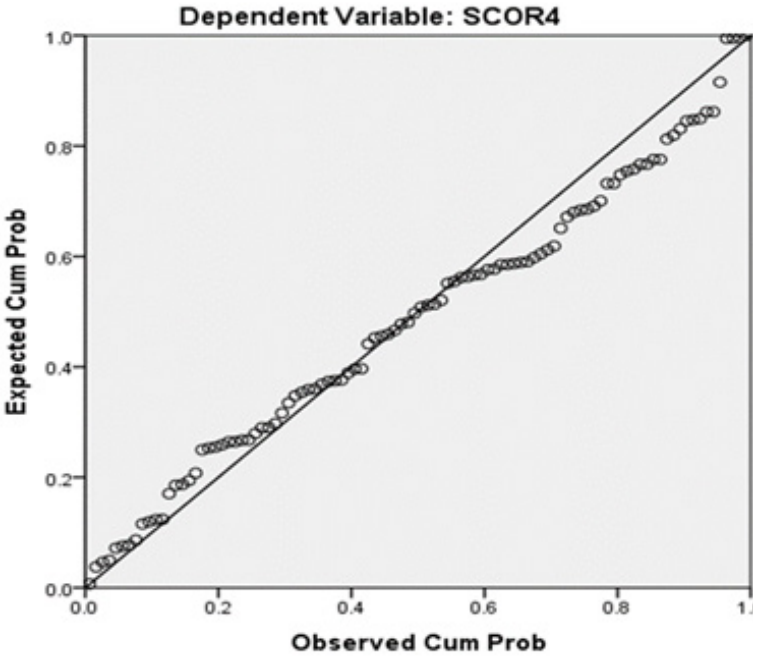

Gambar 1. Hasil Normalitas Dengan Grafic P-plot

Hasil olah data primer, 2016

Hasil grafik plot normal dapat diketahui berada di sepanjang garis $45 \square$, sedangkan nilai signifikasi Kolmogorov-Smirnov pada Asymp. Signifikansi lebih besar dari 5\% $(0,05)$ yaitu sebesar 0,452 maka dapat disimpulkan bahwa data tersebut berdistribusi normal, sehingga dapat digunakan dalam penelitian.

\section{Uji Multikonilieritas}

Pengujian mutlikolinearitas dilakukan untuk meyakini bahwa antar variabel bebas tidak memiliki multikolinearitas atau tidak memiliki hubungan korelasi antara variabel yang ditetapkan sebagai model dalam penelitian, karena model regresi yang baik seharusnya tidak terjadi korelasi di antara variabel independen. Uji multikolinearitas dilakukan dengan melihat nilai Tolerance Value dan Variance Inflation Factor (VIF). Adapun hasil pengujiannya sebagai berikut:

Tabel 7. Hasil Uji Multikolinieritas dengan Collinierity Statistic

\begin{tabular}{|c|c|c|c|c|c|c|c|}
\hline \multirow{3}{*}{ Model } & \multirow{2}{*}{\multicolumn{2}{|c|}{$\begin{array}{l}\text { Unstandardized } \\
\text { Coefficients }\end{array}$}} & \multirow{3}{*}{\begin{tabular}{|c|}
$\begin{array}{c}\text { Standardized } \\
\text { Coefficients }\end{array}$ \\
Beta \\
\end{tabular}} & \multirow{3}{*}{$t$} & \multirow{3}{*}{ Sig. } & \multirow{2}{*}{\multicolumn{2}{|c|}{ Collinearity Statistics }} \\
\hline & & & & & & & \\
\hline & $\mathrm{B}$ & Std. Error & & & & Tolerance & VIF \\
\hline $\begin{array}{l}\text { Kepuasan } \\
\text { Pelanggan }\end{array}$ & 19.392 & 4.172 & & 4.648 & .000 & & \\
\hline $\begin{array}{l}\text { Kualitas } \\
\text { Pelayanan }\end{array}$ & .037 & .072 & .039 & .512 & .610 & .998 & 1.002 \\
\hline Harga & .467 & .054 & .660 & 8.589 & .000 & .993 & 1.007 \\
\hline Kualitas Produk & .002 & .067 & .002 & .030 & .976 & .991 & 1.009 \\
\hline
\end{tabular}

Sumber data : Hasil pengolahan dengan SPSS 2.0, Juli 2016

Berdasarkan hasil pengujian pada tabel di atas, nilai tolerance masing-masing variabel bebas yaitu $<1,0$ dan nilai Variance Inflation Factor (VIF) $<10$, dengan demikian model regresi ini tidak ada multikolinearitas.

\section{Uji Heteroskesdastisitas} berikut:

Hasil uji heteroskedastisitas adalah sebagai

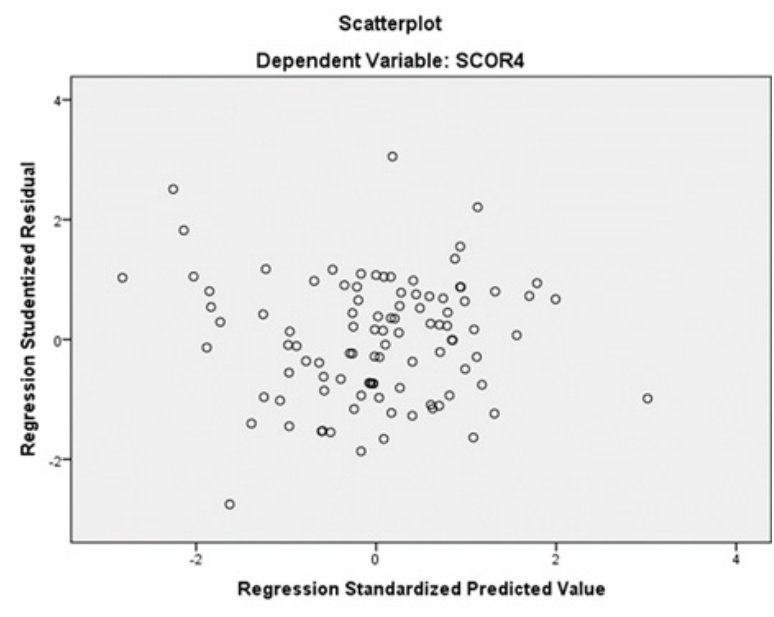

Gambar 2. Hasil Uji Heteroskedastisitas

Berdasarkan gambar 2 diatas menunjukan bahwa pengaruh antara kualitas pelayanan, Harga dan Kualitas Produk terhadap Kepuasan Pelanggan tidak terjadi problem Heteroskedastisitas, hal ini dibuktikan dengan titiktitik menyebar secara acak atau tidak beraturan serta meyebar baik diatas maupun dibawah angka 0 pada sumbu $Y$ dan tidak membentuk pola tertentu, maka disimpulkan bahwa pada uji ini tidak terjadi heteroskedastisitas..

\section{Hasil Analisis Data}

\section{Analisis Regresi Linier Sederhana}

Berdasarkan perhitungan regresi berganda menggunakan program IBM SPSS (Statistical Program for Social Science) versi 24.00 for windows, diperoleh hasil sebagai berikut :

\begin{tabular}{|c|c|c|c|c|c|}
\hline \multicolumn{6}{|c|}{\begin{tabular}{|c|} 
Tabel 8. Hasil Uji Regresi Linier Sederh \\
Pelayanan $\left(\mathrm{X}_{1}\right)$ Terhadap Kepuasa
\end{tabular}} \\
\hline \multicolumn{6}{|c|}{ Coefficients ${ }^{\mathrm{a}}$} \\
\hline \multirow[t]{2}{*}{ 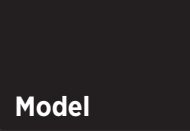 } & \multicolumn{2}{|c|}{$\begin{array}{l}\text { Unstandardized } \\
\text { Coefficients }\end{array}$} & \multicolumn{3}{|c|}{ Standardized Coefficients } \\
\hline & B & Std. Error & Beta & $t$ & Sig. \\
\hline 1 (Constant) & 36.725 & 3.607 & & 10.182 & .000 \\
\hline $\begin{array}{l}\text { Kualitas Pelayanan } \\
\left(X_{1}\right)\end{array}$ & .034 & .094 & .037 & .363 & .718 \\
\hline
\end{tabular}

Dari hasil perhitungan pada tabel di atas dapat disajikan ke dalam bentuk persamaan

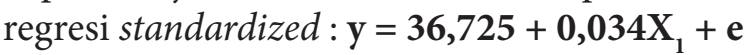

Berdasarkan output nilai koefisien diatas 
dapat disimpulkan koefisien regresi kualitas pelayanan bernilai positif terhadap kepuasan pelanggan. Dari hasil penelitian ini diperoleh nilai koefisien regresi untuk variabel kualitas pelayanan sebesar 0,034 dengan nilai signifikansi 0,718 , sehingga dapat dikatakan bahwa kualitas pelayanan $\left(\mathrm{X}_{1}\right)$ berpengaruh positif terhadap kepuasan pelanggan (Y). Pengaruh positif dapat diartikan bahwa semakin meningkat kualitas pelayanan, maka kepuasan pelanggan juga semakin meningkat.

\begin{tabular}{|c|c|c|c|c|c|}
\hline \multicolumn{6}{|c|}{$\begin{array}{l}\text { Tabel 9. Hasil Uji Regresi Linier Sederhana Antara Harga } \\
\left(X_{2}\right) \text { Terhadap Kepuasan Pelanggan }(Y)\end{array}$} \\
\hline \multicolumn{6}{|c|}{ Coefficients ${ }^{\mathrm{a}}$} \\
\hline \multirow[b]{2}{*}{ Model } & \multicolumn{2}{|c|}{$\begin{array}{l}\text { Unstandardized } \\
\text { Coefficients }\end{array}$} & \multicolumn{3}{|c|}{ Standardized Coefficients } \\
\hline & B & Std. Error & Beta & $\mathrm{t}$ & Sig. \\
\hline 1 (Constant) & 20.869 & 1.983 & & 10.526 & .000 \\
\hline $\operatorname{Harga}\left(X_{2}\right)$ & .467 & .054 & .660 & 8.697 & .000 \\
\hline
\end{tabular}

Dari hasil perhitungan pada tabel di atas dapat disajikan ke dalam bentuk persamaan regresi standardized: $\mathbf{y}=\mathbf{2 0 , 8 6 9}+\mathbf{0 , 4 6 7 X _ { 2 } + e}$

Berdasarkan output nilai koefisien diatas dapat disimpulkan koefisien regresi kualitas pelayanan bernilai positif terhadap kepuasan pelanggan. Dari hasil penelitian ini diperoleh nilai koefisien regresi untuk variabel kualitas pelayanan sebesar 0,467 dengan nilai signifikansi 0,000 , sehingga dapat dikatakan bahwa harga $\left(\mathrm{X}_{2}\right)$ berpengaruh positif terhadap kepuasan pelanggan (Y) atau dapat dikatakan berpengaruh terhadap kepuasan pelanggan.

\begin{tabular}{|c|c|c|c|c|c|}
\hline \multicolumn{6}{|c|}{$\begin{array}{l}\text { Tabel 10. Hasil Uji Regresi Linier Sede } \\
\text { Produk }\left(\mathrm{X}_{3}\right) \text { Terhadap Kepuasan }\end{array}$} \\
\hline \multicolumn{6}{|c|}{ Coefficients ${ }^{\mathrm{a}}$} \\
\hline \multirow[b]{2}{*}{ Model } & \multicolumn{2}{|c|}{$\begin{array}{l}\text { Unstandardized } \\
\text { Coefficients }\end{array}$} & \multicolumn{3}{|c|}{ Standardized Coefficients } \\
\hline & B & Std. Error & Beta & $t$ & Sig. \\
\hline 1 (Constant) & 35.952 & 3.560 & & 10.100 & .000 \\
\hline Produk $\left(X_{3}\right)$ & .052 & .088 & .059 & .585 & .560 \\
\hline
\end{tabular}

Dari hasil perhitungan pada tabel di atas dapat disajikan ke dalam bentuk persamaan regresi standardized: $\mathbf{y}=\mathbf{3 5 , 9 5 2}+\mathbf{0 , 0 5 2} \mathrm{X}_{3}+\mathbf{e}$

Berdasarkan output nilai koefisien diatas dapat disimpulkan koefisien regresi kualitas pelayanan bernilai positif terhadap kepuasan pelanggan. Dari hasil penelitian ini diperoleh nilai koefisien regresi untuk variabel kualitas pelayanan sebesar 0,467 dengan nilai signifikansi 0,000 , sehingga dapat dikatakan bahwa harga $\left(\mathrm{X}_{3}\right)$ berpengaruh positif terhadap kepuasan pelanggan (Y) atau dapat dikatakan berpengaruh terhadap kepuasan pelanggan.

\section{Analisis Regresi Berganda}

Analisis regresi berganda dimaksudkan untuk mengetahui seberapa besar pengaruh variabel promosi $\left(\mathrm{X}_{1}\right)$ dan produk $\left(\mathrm{X}_{2}\right)$ terhadap minat beli (Y). Berdasarkan perhitungan regresi berganda menggunakan program IBM SPSS (Statistical Program for Social Science) versi 22.00 for windows, diperoleh hasil sebagai berikut :

\begin{tabular}{|l|r|r|r|r|r|}
\hline \multicolumn{6}{|c|}{ Tabel 11. Hasil Uji Regresi Berganda } \\
\hline \multirow{2}{*}{ Model } & $\begin{array}{c}\text { Unstandardized } \\
\text { Coefficients }\end{array}$ & \multicolumn{2}{|c|}{ Standardized Coefficients } \\
\hline & \multicolumn{1}{|c|}{ B } & Std. Error & \multicolumn{1}{c|}{ Beta } & \multicolumn{1}{c|}{ t } & \multicolumn{1}{c|}{ Sig. } \\
\hline 1 (Constant) & 19.392 & 4.172 & & 4.648 & .000 \\
\hline Kualitas Pelayanan & .037 & .072 & .039 & .512 & .610 \\
\hline Harga & .467 & .054 & .660 & 8.589 & .000 \\
\hline Kualitas Produk & .002 & .067 & .002 & .030 & .976 \\
\hline a. Dependent Variable: Kepuasan Pelanggan \\
\hline \multicolumn{7}{|c|}{ Sumber : Data primer diolah } \\
\hline
\end{tabular}

Berdasarkan hasil perhitungan pada tabel di atas dapat disajikan ke dalam bentuk persamaan regresi standardized sebagai berikut :

$\mathrm{Y}=19,392+0,037 \mathrm{X}_{1}+0,467 \mathrm{X}_{2}+0,002 \mathrm{X}_{3}$ Keterangan:

$\mathrm{Y}=$ Kepuasan Pelanggan

$\mathrm{X} 1=$ Variabel Kualitas Pelayanan

$\mathrm{X} 2$ = Variabel Harga

$\mathrm{X} 3=$ Variabel Kualitas Produk

Adapun persamaan tersebut dapat dijelaskan sebagai berikut:

a. Nilai konstanta diperoleh sebesar 19.392, menyatakan bahwa tanpa dipengaruhi oleh variabel kualitas pelayanan, harga dan kualitas produk besarnya nilai minat beli sudah terbentuk sebesar 19.392 point.

b. Variabel Kualitas Pelayanani $\left(\mathrm{X}_{1}\right)$ berpengaruh positif dan signifikan terhadap kepuasan pelanggan (Y) dengan nilai koefisien sebesar 0,037. Hal ini diartikan bahwa jika variabel kualitas pelayanan $\left(\mathrm{X}_{1}\right)$ meningkat satu satuan dengan asumsi variabel harga $\left(\mathrm{X}_{2}\right)$ dan kualitas produk $\left(\mathrm{X}_{3}\right)$ tetap atau konstan $(0)$, maka minat beli $(\mathrm{Y})$ juga akan mengalami peningkatan 0,037 
satuan.

c. Variabel Harga $\left(\mathrm{X}_{2}\right)$ berpengaruh positif dan signifikan terhadap kepuasan pelanggan (Y) dengan nilai koefisien sebesar 0,467. Hal ini diartikan bahwa jika variabel harga $\left(\mathrm{X}_{2}\right)$ meningkat satu satuan dengan asumsi variabel kualitas pelayanan (X1) dan kualitas produk $\left(\mathrm{X}_{3}\right)$ tetap atau konstan (0), maka kepuasan pelanggan (Y) juga akan mengalami peningkatan sebesar 0,467 satuan.

d. Variabel Kualitas Produk $\left(\mathrm{X}_{3}\right)$ berpengaruh positif dan signifikan terhadap kepuasan pelanggan $(\mathrm{Y})$ dengan nilai koefisien sebesar 0,002. Hal ini diartikan bahwa jika variabel kualitas produk $\left(\mathrm{X}_{3}\right)$ meningkat satu satuan dengan asumsi variabel kualitas pelayanan $\left(\mathrm{X}_{1}\right)$ dan kualitas harga $\left(\mathrm{X}_{2}\right)$ tetap atau konstan (0), makakepuasan pelanggan (Y) juga akan mengalami peningkatan sebesar 0,002 satuan.

\section{Analisis Koefisien Determinasi}

Analisis koefisien deteminasi (Kd) digunakan untuk mengetahui kontribusi besarnya pengaruh antara variabel bebas terhadap variabel terikat, dalam hal ini adalah variabel promosi dan produk baik secara parsial maupun secara bersama-sama terhadap minat beli. Uji koefisien determinasi $\left(\mathrm{R}^{2}\right)$ menunjukkan nilai $\mathrm{R}$ sebesar 0,661. Hal ini berarti bahwa hubungan atau korelasi antara faktor-faktor yang mempengaruhi keputusan pembelian adalah cukup kuat karena $>0,50$. Nilai $R$ Square sebesar 0,437 atau 43,7\%, ini menunjukkan bahwa variabel kepuasan pelanggan dapat di pengaruhi oleh kualitas pelayanan, harga dan kualitas produk yang dipakai sebagai varabel didalam penelitian ini.

\section{Pengujian Hipotesis}

Pengujian hipotesis dimaksudkan untuk menetukan apakah sebaiknya hipotesis diterima atau ditolak. Dalam pengujian ini digunakan uji t (parsial) dan uji F (Simultan).

\section{a. Uji Hipotesis Parsial (Uji t)}

Pengujian hipotesis secara parsial menggunakan uji t yaitu untuk menguji bagaimana pengaruh masing-masing variabel bebas secara sendiri-sendiri terhadap variabel terikatnya. Hipotesis Pertama :

Terdapat pengaruh positif dan signifikan antara kualitas pelayanan terhadap kepuasan pelanggan

Hipotesis Kedua :

Terdapat pengaruh positif dan signifikan antara harga terhadap kualitas pelayanan .

Hipotesis Ketiga :

Terdapat pengaruh positif dan signifikan antara kualitas produk terhadap kepuasan pelanggan.

\begin{tabular}{|l|r|r|r|r|r|}
\hline \multicolumn{6}{|c|}{$\begin{array}{c}\text { Tabel 12. Pengujian Hipotesis Variabel Kualitas Pelayanan, } \\
\text { Harga dan Kualitas Produk terhadap Kepuasan Pelanggan }\end{array}$} \\
\hline \begin{tabular}{l|r|r|r|r|} 
Variabel \\
\hline $\begin{array}{l}\text { Kualitas } \\
\text { Pelayanan }\end{array}$
\end{tabular} & 0.037 & 0.512 & 1,988 & 0.610 & $H_{0}$ Diterima \\
\hline Harga & 0.467 & 8.589 & 1,988 & 0.000 & $H_{0}$ Ditolak \\
\hline $\begin{array}{l}\text { Kualitas } \\
\text { Produk }\end{array}$ & 0.002 & 0.030 & 1,988 & 0.976 & $H_{0}$ Diterima \\
\hline \multicolumn{7}{|c|}{ t tabel } & \multicolumn{1}{c|}{ Sig.t } & \multicolumn{1}{|c|}{ Keputusan } \\
\hline
\end{tabular}

Berdasarkan hasil pengolahan data di atas, diperoleh :

Kualitas Pelayanan terhadap Kepuasan Pelanggan

Nilai $\mathrm{t}_{\text {hitung }}<\mathrm{t}_{\text {tabel }}$ atau $(0,512>1,984)$, dengan signifikansi $0,610>0,05$. Dengan demikian hipotesis pertama yang menyatakan tidak terdapat pengaruh positif dan signifikan antara kualitas pelayanan terhadap kepuasan pelanggan.

Harga terhadap Kepuasan Pelanggan

Nilai $\mathrm{t}_{\text {hitung }}>\mathrm{t}_{\text {tabel }}$ atau $(8,589>1,984)$, dengan signifikansi $0,00<0,05$. Dengan demikian hipotesis kedua yang menyatakan terdapat pengaruh positif dan signifikan antara harga terhadap kepuasan pelanggan.

Kualitas Produk terhadap Kepuasan Pelanggan

Nilai $\mathrm{t}_{\text {hitung }}<\mathrm{t}_{\text {tabel }}$ atau $(0,030<1,984)$, dengan signifikansi 0,97>0,05. Dengan demikian hipotesis ketiga yang menyatakan tidak terdapat pengaruh positif dan signifikan antara kualitas produk terhadap kepuasan pelanggan.

\section{b. Uji Hipotesis Secara Simultan (Uji F)} Berikut adalah hasil yang dapat dari uji $\mathrm{F}$

\begin{tabular}{|c|c|c|c|c|c|c|}
\hline \multicolumn{7}{|c|}{ Tabel 13. Hasil Uji F } \\
\hline \multicolumn{7}{|c|}{ ANOVAa $^{a}$} \\
\hline \multicolumn{2}{|c|}{ Model } & $\begin{array}{l}\text { Sum of } \\
\text { Squares }\end{array}$ & df & $\begin{array}{l}\text { Mean } \\
\text { Square }\end{array}$ & $\mathbf{F}$ & Sig. \\
\hline \multirow{3}{*}{1} & Regression & 283.684 & 3 & 94.561 & 24.855 & $.000^{\mathrm{b}}$ \\
\hline & Residual & 365.226 & 96 & 3.804 & & \\
\hline & Total & 648.910 & 99 & 0 & & \\
\hline \multicolumn{7}{|c|}{$\begin{array}{l}\text { a. Dependent Variable : Kepuasan Pelanggan } \\
\text { b. Predictors: (Constant) : Kualitas Pelayanan, Harga, dan Kualitas Produk }\end{array}$} \\
\hline \multicolumn{7}{|c|}{ Sumber : Pengolahan data primer } \\
\hline
\end{tabular}


Dari output data diatas diketahui bahwa nilai $\mathrm{F}_{\text {Hitung }}$ sebesar 24.855 dengan signifikansi 0,000 dan F Tabel sebesar 2,70 sehingga $\mathrm{F}_{\text {Hitung }}>$ $\mathrm{F}_{\text {Tabel }}$ maka $\mathrm{H}_{0}$ ditolak dan $\mathrm{H}_{1}$ diterima. Artinya kualitas pelayanan $\left(\mathrm{X}_{1}\right)$, harga $\left(\mathrm{X}_{2}\right)$ dan kualitas produk $\left(\mathrm{X}_{3}\right)$ bersama-sama memberikan pengaruh yang signfikan terhadap kepuasan pelang$\operatorname{gan}(\mathrm{Y})$.

\section{Hasil dan Pembahasan}

Dari hasil pengujian statistik dan analisis diatas, maka dapat dipaparkan analisis pengaruh kualitas pelayanan, harga dan kualitas produk terhadap kepuasan pelanggan instrumentasi penunjang laboratorium di PT Laborindo Sarana sebagai berikut :

1. Pengaruh kualitas pelayanan terhadap kepuasan pelanggan PT Laborindo Sarana

Dari hasil analisis statistik, diperoleh persamaan model regresi adalah $\mathrm{y}=36,725+$ $\mathbf{0 , 0 3 4 X _ { 1 }}+$ e. Konstansta memiliki nilai positif sehingga apabila kualitas pelayanan mengalami kenaikan, maka kepuasan pelanggan juga akan meningkat.

Koefisien korelasi antara kualitas pelayanan terhadap kepuasan pelanggan adalah sebesar 0,037 . Dengan demikian dapat dikatakan bahwa kedua variabel memiliki hubungan yang positif sebesar 0,037. Nilai Koefisien Determinasi Adjusted $R$ Square sebesar 0,041. Dari data tersebut memperlihatkan bahwa kualitas pelayanan hanya berpengaruh sebesar $4,1 \%$ terhadap kepuasan pelanggan instrumentasi penunjang laboratorium.

Pada Uji $\mathrm{t}$, nilai $\mathrm{t}_{\text {hitung }}$ 0,512 lebih kecil dibandingkan dengan nilai $\mathrm{t}_{\text {tabel }} 1.988$ dengan demikian $\mathrm{t}_{\text {hitung }}<\mathrm{t}_{\text {tabel }}$ dengan taraf signifikansi $0,610>0,05$. Hal ini menunjukkan bahwa Kualitas Pelayanan $\left(\mathrm{X}_{1}\right)$ memiliki pengaruh positif tapi tidak signifikan terhadap Kepuasan Pelanggan (Y) Instrumentasi PT Laborindo Sarana.

\section{Pengaruh harga terhadap kepuasan pelanggan PT Laborindo Sarana}

Dari hasil analisis statistik, diperoleh persamaan model regresi adalah $\mathrm{y}=\mathbf{2 0 , 8 6 9 +}$ $\mathbf{0 , 4 6 7 X _ { 2 }}+$ e. Konstansta memiliki nilai positif sehingga apabila harga kompetitif maka kepuasan pelanggan juga akan meningkat.
Koefisien korelasi antara harga terhadap kepuasan pelanggan adalah sebesar 0,467. Dengan demikian dapat dikatakan bahwa kedua variabel memiliki hubungan yang positif sebesar 0,467. Nilai Koefisien Determinasi Adjusted $R$ Square sebesar 0,330. Dari data tersebut memperlihatkan bahwa Harga hanya berpengaruh sebesar 33.0\% terhadap kepuasan pelanggan instrumentasi penunjang laboratorium.

Pada Uji t, nilai $\mathrm{t}_{\text {hitung }} 8.589$ lebih besar dibandingkan dengan nilai $\mathrm{t}_{\text {tabel }} 1.988$ dengan demikian $\mathrm{t}_{\text {hitung }}>\mathrm{t}_{\text {tabel }}$ dengan taraf signifikansi $0,000<0,05$. Hal ini menunjukan bahwa Harga $\left(\mathrm{X}_{2}\right)$ memiliki pengaruh positif dan signifikan terhadap Kepuasan Pelanggan (Y) Instrumentasi PT Laborindo Sarana.

\section{Pengaruh kualitas produk terhadap ke- puasan pelanggan PT Laborindo Sarana}

Dari hasil analisis statistik, diperoleh persamaan model regresi $\mathbf{y}=\mathbf{3 5 , 9 5 2}+\mathbf{0 , 0 5 2 X _ { 3 } +}$ e. Konstansta memiliki nilai positif sehingga apabila kualitas produk maka kepuasan pelanggan juga akan meningkat.

Koefisien korelasi antara kualitas produk terhadap kepuasan pelanggan adalah sebesar 0,002 . Dengan demikian dapat dikatakan bahwa kedua variabel memiliki hubungan yang positif sebesar 0,002. Nilai Koefisien Determinasi Adjusted $R$ Square sebesar 0,005. Dari data tersebut memperlihatkan bahwa kualitas produk hanya berpengaruh sebesar 5.0\% terhadap kepuasan pelanggan instrumentasi penunjang laboratorium.

Pada Uji t, nilai $t_{\text {hitung }} 0,030$ lebih kecil dibandingkan dengan nilai $\mathrm{t}_{\text {tabel }} 1.988$ dengan demikian $\mathrm{t}_{\text {hitung }}<\mathrm{t}_{\text {tabel }}$ dengan taraf signifikansi 0,976 $>0,05$. Hal ini menunjukan bahwa Kualitas Produk $\left(\mathrm{X}_{2}\right)$ memiliki pengaruh positif tapi tidak signifikan terhadap Kepuasan Pelanggan (Y) Instrumentasi PT Laborindo Sarana.

\section{Pengaruh kualitas pelayanan, harga dan kualitas produk terhadap kepuasan pelanggan PT Laborindo Sarana. \\ Dari hasil analisis statistik, Model regresi} yang diperoleh adalah $y=19,392+0,037 X_{1}+$ $\mathbf{0 , 4 6 7 X}_{2}+\mathbf{0 , 0 0 2 X}_{3}$. Konstanta sebesar 19,392 menyatakan bahwa tanpa kualitas pelayanan, harga dan kualitas produk, kepuasan pelanggan yang terbentuk sebesar 19,392. Konstansta 
memiliki nilai positif sehingga apabila kualitas pelayanan,harga dan kualitas produkmengalami kenaikan, maka kepuasan pelanggan juga akan meningkat.

Dari output data diatas diketahui bahwa nilai $\mathrm{F}_{\text {Hitung }}$ sebesar 24.855 dengan signifikansi 0,000 dan $\mathrm{F}_{\text {Tabel }}$ sebesar 2,70 sehingga $\mathrm{F}_{\text {Hitung }}>$ $\mathrm{F}_{\text {Tabel }}$ maka $\mathrm{H}_{0}$ ditolak dan $\mathrm{H}_{1}$ diterima. Artinya kualitas pelayanan $\left(\mathrm{X}_{1}\right)$, harga $\left(\mathrm{X}_{2}\right)$ dan kualitas produk $\left(\mathrm{X}_{3}\right)$ bersama- sama memberikan pengaruh yang signfikan terhadap kepuasan pelanggan $(\mathrm{Y})$ Instrumentasi PT Laborindo Sarana. Nilai Koefisien Determinasi Adjusted $R$ Square sebesar 0,420. Data tersebut mengindikasikan bahwa kualitas pelayanan, harga dan kualitas produk terhadap kepuasan pelanggan memberikan kontribusi sebesar $42 \%$, sisanya sebesar 58\% dijelaskan oleh vaiabel lain diluar penelitian ini.

\section{KESIMPULAN DAN SARAN \\ Kesimpulan}

Setelah penulis melakukan penelitian dan analisis mengenai pengaruh promosi dan produk terhadap minat beli pada PT. Asuransi Jiwa Recapital di Jakarta, seperti yang telah dipaparkan pada bab-bab sebelumnya, maka penulis dapat menarik kesimpulan sebagai berikut:

1. Kualitas pelayanan berpengaruh positif tapi tidak siginifikan terhadap kepuasan pelanggan instrumentasi penunjang laboratorium PT Laborindo Sarana.

2. Harga berpengaruh positif dan signifikan terhadap kepuasan pelanggan instrumentasi penunjang laboratorium PT Laborindo Sarana.

3. Kualitas Produk berpengaruh positif tapi tidak signifikan terhadap kepuasan pelanggan penunjang instrumentasi laboratorium PT Laborindo Sarana.

4. Kualitas pelayanan, harga dan kualitas produk memberikan pengaruh sebesar $42 \%$ terhadap kepuasan pelanggan instrumentasi penunjang laboratorium PT Laborindo Sarana.

\section{Saran}

Berdasarkan kesimpulan di atas, maka penulis mengajukan beberapa saran yang diharapkan dapat bermanfaat bagi PT. Laborindo
Sarana. Adapun saran tersebut adalah sebagai berikut:

1. Dari hasil penelitian diketahui bahwa variabel kualitas pelayanan pada indikator Responsiveness dan Reliabilty memiliki skor yang rendah, oleh karena itu PT Laborindo Sarana disarankan kedepannya lebih meningkatkan Kualitas Pelayanan dari segi Responsiveness yaitu dengan : Mempercepat proses penerimaan PO (Purchase Order dari pelanggan ke perusahaan), dan mempercepat proses supplai barang ke pelanggan.

2. Untuk kedepannya PT Laborindo Sarana harus lebih memperhatikan kemampuan karyawan dalam product knowledge, dengan melakukan training secara berkala untuk penguasaan produk yang dijual.

3. Dari hasil penelitian diketahui Variabel harga pada indikator persaingan memiliki skor yang paling rendah. Untuk itu disarankan PT Laborindo Sarana untuk menetapkan harga yang sesuai dengan kualitas produk dan kualitas pelayanan serta kondisi pasar yang ada saat ini.

4. Dari hasil penelitian diketahui Variabel kualitas produk pada indikator kesesuaian memiliki skor yang paling rendah.Untuk itu disarankan PT Laborindo Sarana lebih mempelajari detai setiap produk yang dijual dan menggali lebih dalam apa yang menjadi prioritas kebutuhan pelanggannya.

\section{DAFTAR PUSTAKA}

Ariawan, Iwan, 1998. Besar dan Metode Sampel Pada Penelitian Kesehatan. Jurusan Biosatistik dan Kependudukan Fakultas Kesehatan Masyarakat Universitas Indonesia.

Azhari, 2001. Hubungan Antara Faktor Internal dan Faktor Eksternal Dengan Prestasi Belajar Siswa Di SPK Depkes Lubuk Linggau Tahun 2001. Tesis Program Pasca Sarjana Ilmu Kesehatan Masyarakat, Fakutas Kesehatan Masyarakat Universitas Indonesia, Depok. Azwar, Saifuddin. 1998. Tes Prestasi Fungsi dan Pengembangan Pengukutan Prestasi Belajar. Yogyakarta: Pustaka Pelajar Offset.

Anwar Prabu Mangkunegara. 2006. Evaluasi Kinerja SDM. Bandung: Refika Aditama, Arikunto, S. 1983. Metode Research. Jakarta: 
Rajawali Pers.

Chandra, Budiman. 1995. Pengantar Statistik Kesehatan. Jakarta: Penerbit Buku Kedokteran EGC.

Chandra, Ardhian. 2016. Pengaruh Kualitas Pelayanan dan Bauran Pemasaran terhadap Loyalitas Pelanggan melalui Kepuasan Pelanggan dan Brand Loyality pada PT.Laborindo Sarana. Tesis Program Pasca Sarjana Ilmu Manajemen, Fakultas Ekonomi, Universitas Pancasila. Depok.

Depdikbud, 1994. Kamus Besar Bahasa Indonesia. Jakarta: Balai pustaka.

Deswarto. 2001. Hubungan Antara Motivasi Belajar Dan hasil Ujian Seleksi Masuk Dengan Prestasi Belajar Mahasiswa Di Akademi Keperawatan Departemen Kesehatan Palembang Propinsi Sumatera Selatan Tahun 2001. Skripsi Program Sarjana Fakutas Kesehatan Masyarakat Universitas Indonesia, Depok.

Djamarah, Syaiful Bakri, 1994. Prestasi Belajar dan Kompetensi Guru. Surabaya: Usaha Nasional.

Endranto, Agung Jaya. 2001. Hubungan Antara Nilai Ujian Masuk FKM UI Dengan Indeks Prestasi Pada mahasiswa SKM Jalur B Angkatan tahun 1998 dan 1999/2000. Skripsi Program Sarjana Fakutas Kesehatan Masyarakat Universitas Indonesia, Depok.

Ghozali. 2005. Analisis Multivariant dengan Program SPSS. Semarang: UNDIP.

Gulo, W. 2005. Strategi Belajar Mengajar. Jakarta: PT Gramedia Widiasarana Indonesia.

Hague, Paul. 1995. Merancang Kuesioner. Jakarta: Pustaka Binaman Pressindo.

Hatta, Gemala R. 2008. Pedoman Manajemen Informasi Kesehatan di Sarana Pelayanan Kesehatan (Revisi). Jakarta: UI Press

Hastono, Sutanto Priyo. 2007. Analisis Data Kesehatan. Jakarta: Fakultas Kesehatan Masyarakat Universitas Indonesia.

Hastono, Sutanto Priyo. 2001. Analisis Data. Jakarta: Fakultas Kesehatan Masyarakat Universitas Indonesia.

Hidayat, Eka Putra Syarif. 2003. Hubungan Nilai Ujian Masuk Dan Motivasi Dengan Prestasi Belajar Mahasiswa Jurusan Teknik Radiodiagnostik Politeknik Kesehatan Jakarta II Departemen Keshatan Tahun 2003. Tesis Program Pasca Sarjana Ilmu Kesehatan Masyarakat, Fakutas Kesehatan
Masyarakat Universitas Indonesia, Depok.

Kementerian Kesehatan, 2010. Kurikulum Pendidikan Diploma III. Politeknik Kesehatan Kemenkes Jakarta II.

Kementerian Kesehatan, 2013. Profil Politeknik Kesehatan Kemenkes Jakarta II.

Kementerian Kesehatan, 2015. Profil Politeknik Kesehatan Kemenkes Jakarta II.

Kementerian Kesehatan, 2011. Petunjuk Teknis Seleksi Penerimaan Mahasiswa Baru Pendidikan Tenaga Kesehatan, Kementerian Kesehatan Republik Indonesia. Jakarta.

Lemeshow, Stanley, et.all, 1997. Besar Sampel Dalam Penelitian Kesehatan. Yogyakarta: Gajah Mada University Press.

Marehwati, Agung. 2002. Hubungan Antara Hasil Ujian Masuk Sipensimaru Dengan Prestasi Belajar Mahasiswa Akademi Kesehatan Gigi Depkes Propinsi Jambi Tahun Ajaran 2000/2001. Tesis Program Pasca Sarjana Ilmu Kesehatan Masyarakat, Fakutas Kesehatan Masyarakat Universitas Indonesia, Depok.

Masoem,Toemin A. 1997. Kualitas Mahasiswa Baru Perguruan Tinggi Negeri. Jurnal Penelitian Makara UI Volume 2 Seri B Edisi Sosial Ekonomi dan Budaya, Universitas Indonesia. Depok.

Minarto, Riyadi. 1997. Hubungan Antara Nilai Ujian Masuk Dengan Prestasi Belajar Mahasiswa Akademi Perawatan Depkes Tahun 1997. Tesis Program Pasca Sarjana Ilmu Kesehatan Masyarakat, Fakutas Kesehatan Masyarakat Universitas Indonesia. Depok.

Nasution. 1987. Teknologi Pendidikan. Bandung: CV Jemmars.

Nurkencana. 2005. Evaluasi Hasil Belajar Mengajar. Surabaya: Usaha Nasional.

Purwanto, M.N. 2000. Prinsip-prinsip Dan Teknik Evaluasi Pengajaran. Bandung: Remaja Rosda Karya.

Pusdiknakes, 2000. Pedoman Petunjuk Teknis Sipenmaru Poltekkes Kemenkes Jakarta.

Sabri, Luknis dan Sutanto Priyo Hastono, 2008. Statistik Kesehatan (Edisi Revisi). Jakarta : PT Raja Grafindo Persada.

Silalahi, Corina D, dkk, 2001. Persepsi Mahasiswa dan Dosen Fakultas Psikologi Universitas Indonesia Mengenai Kualitas Dosen yang Profesional. Jurnal Penelitian Makara UI Volume 5 Seri Sosial dan 
Humaniora, Universitas Indonesia, Depok. Simanjuntak, Pasaribu. 1980. Proses Belajar Mengajar. Bandung: Penerbit Tarsito.

Slameto. 2003. Belajar dan Faktor-Faktor yang Mempengaruhinya. Jakarta: PT Rineka Cipta.

Sukadji, Soetarlinah, 2000. Sikap dan Kebiasaan Belajar, Indeks Prestasi Kumulatif dan Lama Studi Mahasiswa Psikologi Universitas Indonesia. Jurnal Penelitian Makara UI Volume 4 Seri C Edisi Sosial Ekonomi dan Budaya, Universitas Indonesia, Depok.

Suryabrata, Sumadi. 1997. Psikologi Pendidikan, Manajemen. Jakarta: PT Raja Grafindo Persada.

Turdjai, Heru, 2001. Hubungan Karakteristik mahasiswa Program D III Keperawatan Di DKI Jakarta Dengan prestasi Belajar Pada Mata Kuliah Keperawatan Kesehatan Komuniti Tahun 1999. Tesis Program Pasca Sarjana Ilmu Kesehatan Masyarakat, Fakutas Kesehatan Masyarakat Universitas Indonesia, Depok. 